\title{
SISTEM PELAYANAN DUKUNGAN ROLE ONLINE SYS- TEM TICKETING RAHARJA (ROOSTER) DENGAN MENGGUNAKAN E-TICKET
}

\author{
Untung Rahardja \\ Nur Azizah ${ }^{2}$ \\ Santika Dewi ${ }^{3}$ \\ e-mail: untung@raharja.co,nur.azizah@raharja.co, \\ santika@raharja.co
}

Diterima : 21 April 2012 / Disetujui : 19 April 2013

\begin{abstract}
The development of a more advanced age supports the need to provide different types of services that can be accessed in various ways easily, quickly, efficiently, whenever and wherever. Interactions that were once done physically (direct person to person contact) began to shift to electronic (communication through technology innovations) because relative electronic communications can be done efficiently, effectively, accurate, safe, comfortable, and quality. Therefore, the making of an application system support services and accurate highly recommended. With online methods based systems, system service support will be very easy to obtain. The ROOSTER is an application based support service system that is very practical. In this article describe the issues that arise as well as solving the problems examined. In addition there are three (3) characteristics and 5 (five) advantage of this application. In the implementation shown protoype view of the application ROOSTER. It can be concluded that the contribution of the system to maximize ROOSTER various forms of service, and can be used as media support service system that is valid for the entire academic community colleges and the general public.
\end{abstract}

Keywords: ROOSTER, online, service support.

\section{ABSTRAKSI}

1. Dosen Jurusan Sistem Informasi, STMIK Raharja

Jl. Jend Sudirman No. 40 Modern Cikokol-Tangerang Telp. 5529692

2. Dosen Jurusan Managemen Informasi, AMIK Raharja Informatika Jl. Jend Sudirman No. 40 Modern Cikokol-Tangerang Telp. 5529692

3. Mahasiswa Jurusan Sistem Informasi, STMIK Raharja

Jl. Jend Sudirman No. 40 Modern Cikokol-Tangerang Telp. 5529692 
Perkembangan jaman yang semakin maju mendukung keinginan untuk menyediakan berbagai jenis layanan yang dapat diakses dengan berbagai cara secara mudah, cepat, efisien, kapan pun dan di mana pun. Interaksi yang dulunya dilakukan secara fisik (person to person direct contact) mulai bergeser ke elektronik (communication through technology innovations) karena komunikasi secara elektronik relatif dapat dilakukan secara efisien, efektif, akurat, aman, nyaman, dan berkualitas. Oleh karena itu, pembuatan sebuah aplikasi sistem pelayanan dukungan yang tepat dan akurat sangat disarankan. Dengan metode sistem berbasis online, sistem pelayanan dukungan tersebut akan sangat mudah untuk didapatkan. Adapun ROOSTER merupakan sebuah aplikasi sistem pelayanan dukungan berbasis online yang sangat praktis. Dalam artikel ini di jelaskan mengenai masalahmasalah yang timbul serta pemecahan masalah yang diteliti. Selain itu terdapat 3 (tiga) ciri khas dan 5 (lima) keunggulan dari aplikasi ini. Pada implementasinya ditampilkan tampilan protoype dari aplikasi ROOSTER. Maka dapat disimpulkan bahwa kontribusi sistem ROOSTER dapat memaksimalkan berbagai bentuk pelayanan, serta dapat dijadikan media sistem pelayanan dukungan yang valid bagi seluruh civitas perguruan tinggi dan masyarakat secara umum.

Kata kunci : ROOSTER, online, pelayanan dukungan.

\section{PENDAHULUAN}

Perkembangan teknologi di era globalisasi ini sudah berkembang sangat pesat, dari waktu ke waktu teknologi mengalami perubahan yang sangat besar. Kemajuan teknologi yang sangat pesat ini berdampak pada semua aspek kehidupan yang berhubungan dengan dunia informasi dan teknologi. Diikuti dengan perkembangan teknologi informasi yang terus berkembang dan berinovasi. Sehingga banyak sekali kalangan yang ingin memanfaatkan untuk memenuhi kebutuhan atau mendukung kegiatan. Perkembangan teknologi informasi sekarang ini, banyak masalah yang dapat terselesaikan dengan lebih cepat dan efisien. Seiring dengan perkembangan teknologi Informasi (TI) yang semakin pesat, kebutuhan akan suatu konsep dan mekanisme pelayanan berbasis TI menjadi tidak terelakkan lagi. Konsep yang kemudian terkenal dengan sebutan online ini membawa pengaruh terjadinya proses transformasi pelayanan dukungan ke dalam bentuk digital, baik secara isi (contents) dan sistemnya. Saat ini konsep pelayanan dukungan online sudah banyak diterima oleh masyarakat dunia, terbukti dengan maraknya implementasi pelayanan dukungan online di lembaga pendidikan (sekolah, training dan universitas), industri maupun instansi-instansi lainnya.

Melalui penerapan teknologi sistem informasi untuk membantu proses pelayanan dukungan online dapat lebih mudah dilakukan, sehingga pelayanan pun dapat dilakukan dengan berbagai cara yang diharapkan dan dapat memudahkan 
proses pelayanan. Juga dapat menghasilkan produk dan jasa yang berkualitas tinggi, bersifat global, dan berdaya saing tinggi. Bahkan pada tingkat tertentu, pemanfaatan teknologi sistem informasi secara optimal dapat meningkatkan standar, kualitas dan kemampuan kompetitif institusi pendidikan, dan dapat mendukung pelaksanaan fungsi dan tugas manajerial.

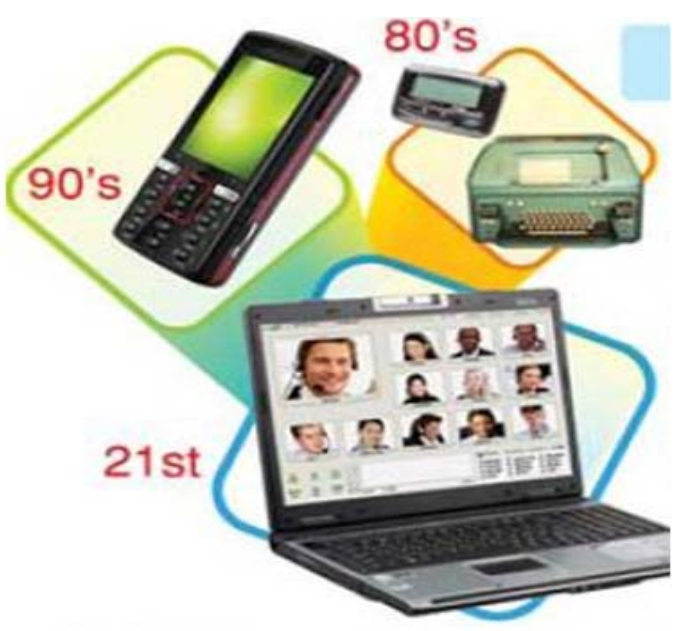

Gambar 1. Perkembangan teknologi informasi

Sistem pelayanan yang berupa website, penggunaannya dalam suatu perusahaan dan organisasi pun semakin banyak. Website juga mempengaruhi popularitas dan brand image dari organisasi tersebut. Organisasi dengan website yang menarik, mudah diakses, dan karya informasi yang up to date, sudah tentu mempunyai popularitas dan brand image yang tinggi walaupun hanya didunia maya. Hal-hal tersebut dapat menambah nilai tambah citra dari suatu perusahaan dan organisasi.

Internet merupakan medium yang sempurna untuk mendukung permintaan layanan, karena internet sanggup membawa jaringan yang luas dan basis kostumer yang besar. Istilah e-ticket (Electronic Ticket) adalah suatu cara untuk mendokumentasikan proses permintaan pelayanan dari aktifitas pelayanan tanpa harus mengeluarkan dokumen berharga secara fisik ataupun paper ticket. Semua informasi mengenai electronic ticketing disimpan secara digital dalam sistem komputer. Sejalan dengan perkembangan teknololgi informasi, internet kini muncul sebagai alternatif sistem permintaan pelayanan dukungan. Adapun pengertian lain $e$ ticketing, atau penjualan tiket online, merupakan salah satu cara bagi orang untuk 
membuat tiket. Fasilitas pemesanan tiket online yang dirancang untuk membantu seluruh civitas akademika, memungkinkan untuk meningkatkan kegiatan sistem pelayanan dukungan secara online melalui situs web.

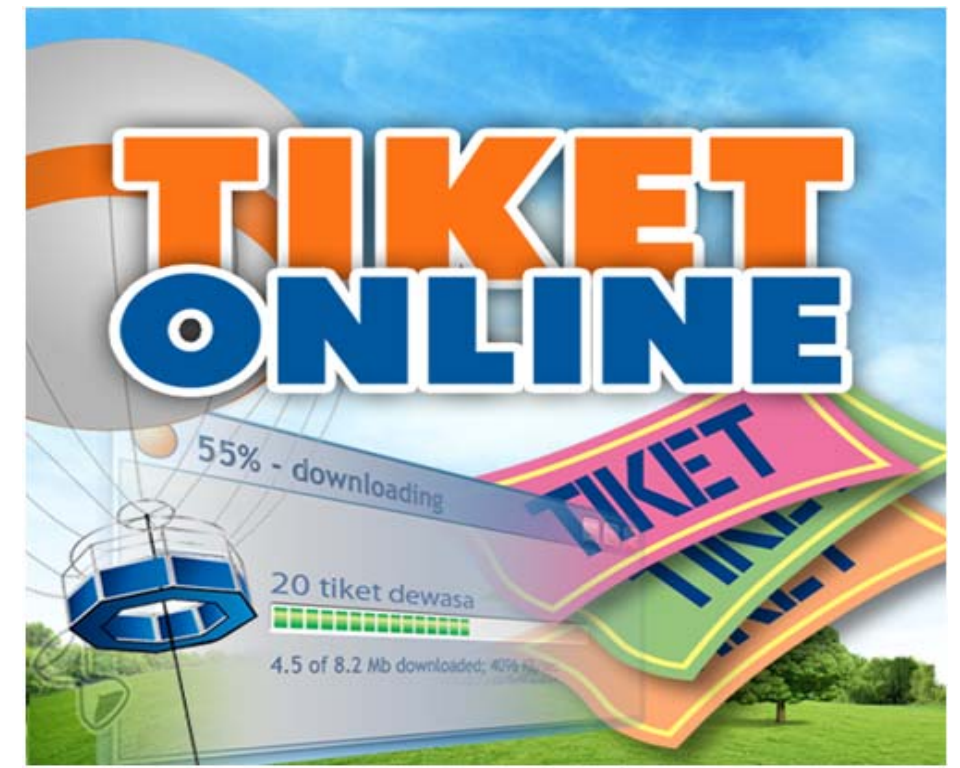

Gambar 2. Tiket online

Tampak pada gambar diatas, menjelaskan sistem e-ticket (Electronic Ticket) atau tiket online yang berupa website, dapat diakses dimanapun dan kapanpun dengan menggunakan akses jaringan internet. Sehingga $e$-ticket (Electronic Ticket) tersebut dapat di jadikan inovasi baru dalam sistem permintaan pelayanan dukungan, sebagai suatu sistem pelayanan baru, dalam permintaan pelayanan dukungan dengan memanfaatkan perkembangan informasi teknologi.

Pada era teknologi seperti ini teknologi e-ticket sangat membantu pelayanan dukungan yang dituntut untuk semakin cepat, mudah dan dinamis. Pada Perguruan Tinggi Raharja, sistem pelayanan dukungan ROOSTER yang diterapkan ditujukan untuk memberikan pelayanan kepada seluruh civitas akademika Perguruan Tinggi Raharja dan memberikan pelayanan yang efektif dan efisien dalam proses pelayanan dukungan sehingga dapat memaksimalkan pelayanan dukungan. Sistem pelayanan dukungan ROOSTER merupakan sebuah website sebagai media interaksi dengan tujuan untuk memudahkan proses pelayanan dukungan, selain itu juga memberikan kemudahan kepada pemakai untuk dilayani. Proses pelayanan dukungan dapat 
dilakukan dengan cara online, sehingga menambah kemudahan dalam proses pelayanan dukungan.

\section{PERMASALAHAN}

Seiring dengan pesatnya laju perkembangan terkini dituntut adanya informasi yang cepat, tepat dan akurat sehingga mengakibatkan persaingan yang semakin kompetitif. Ketatnya persaingan dan pesatnya perkembangan teknologi dan informasi yang ada menuntut suatu sistem menjadi lebih baik, cepat dan handal dalam menyelesaikan suatu masalah tertentu. Dengan berkembangnya teknologi dan kebutuhan akan informasi menyebabkan bertambah kompleksnya informasi yang harus bisa diolah, sehingga kebutuhan pengguna akan jaringan komputer bersamasama semakin diperlukan. Penggunaan jaringan secara bersama-sama ini bertumbuh membentuk jaringan komputer yang sangat besar tersebar diseluruh belahan muka bumi yang dikenal dengan nama internet yang bisa diakses dan dimanfaatkan untuk berbagai keperluan, oleh siapa saja, dimana saja, dan kapan saja.

Pada saat ini seluruh perguruan tinggi juga memiliki sistem pelayanan dukungan untuk melayani permintaan layanan dukungan yang ada di kampus tersebut, begitu pula dengan Perguruan Tinggi Raharja yang telah memiliki sistem pelayanan dukungan. Namun masih terdapat permasalahan yang harus dihadapi saat ini. Dan dalam hal ini terdapat 5 (lima) permasalahan yang ada dalam sistem pelayanan dukungan saat ini, yaitu permasalahan pertama dapat dikatakan masih belum optimal, hal tersebut dikarenakan pendataan yang masih manual. Permasalahan kedua yaitu tidak menyeluruh (tidak update), permasalahan ketiga yaitu menyebabkan kesulitan dalam proses pelayanan dukungan. Sedangkan permasalahan keempat yaitu sistem pelayanan dukungan tidak mencakup seluruh civitas akademika, sehingga hanya segelintir saja yang mengetahui dan mengakses sistem pelayanan dukungan sebagai sarana untuk mendapatkan layanan dukungan. Dan permasalahan yang terakhir yaitu belum teraksesnya secara online, sehingga tidak bisa diakses dimanapun dan kapanpun.

Dari permasalahan yang telah dijabarkan diatas, jelas bahwa sistem pelayanan dukungan pada Perguruan Tinggi Raharja belum optimal dan tidak dapat memberikan pelayanan dukungan yang memuaskan bagi user. Sehingga didalamnya dapat diidentifikasikan secara keseluruhan terdapat 2 (dua) kekurangan yang telah dijabarkan diatas. Maka, untuk itu dari penjelasan di atas, dirumuskan 2 (dua) permasalahan secara keseluruhan yaitu permasalahan pertama, bagaimana meningkatkan secara signifikan pelayanan dukungan yang optimal sehingga dapat 
memenuhi permintaan pelayanan dukungan. Dan permasalahan yang kedua, yaitu bagaimana memudahkan seluruh civitas akademika Perguruan Tinggi Raharja untuk mendapatkan pelayanan dukungan tersebut.

Dari kelima permasalahan diatas dapat disimpulkan secara detail menurut penjabaran tentang sistem pelayanan dukungan yang tercantum dalam aplikasi Mind Mapping. Dikarenakan proses pembuatan aplikasi ini tidak mudah, dan membutuhkan proses yang bertahap, sehingga dilakukan proses pembuatan aplikasi yang sebenarnya.

Berikut tampilan perancangan Mind Mapping aplikasi ROOSTER (Role Online System Ticketing Raharja).

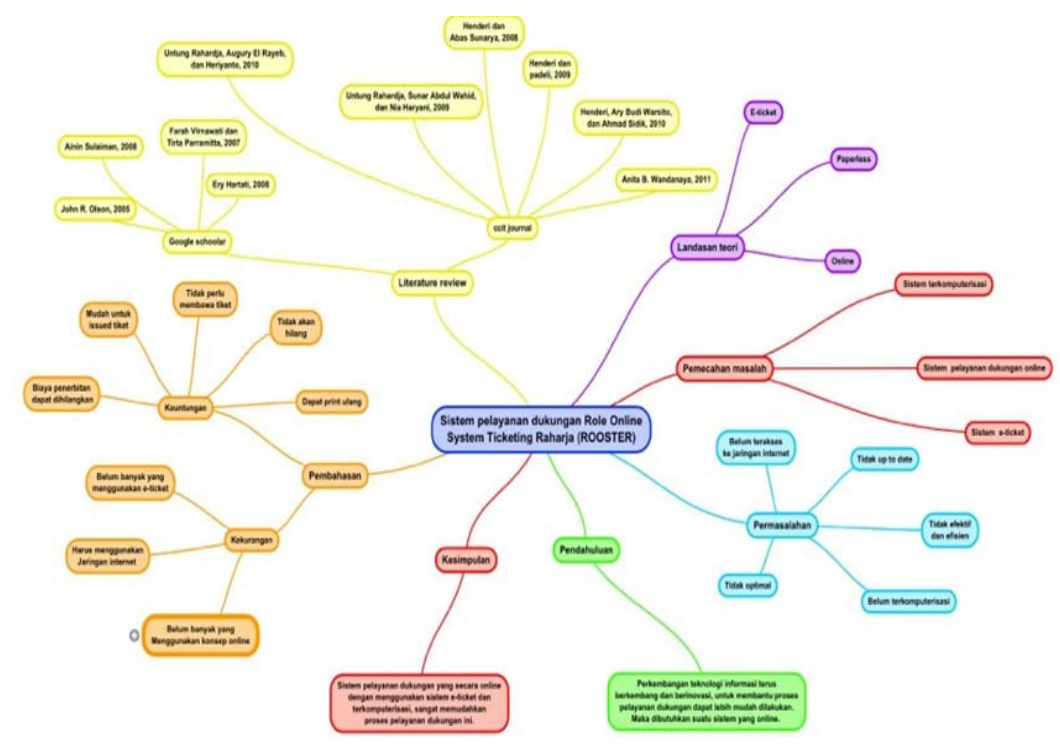

Gambar 3. Mind Mapping penjabaran sistem pelayanan dukungan

Tampak pada gambar diatas adalah Mind Mapping penjabaran perihal ROOSTER (Role Online System Ticketing Raharja). Maka, dengan adanya aplikasi ROOSTER diharapkan sistem pelayanan dukungan dapat berjalan jauh lebih baik lagi, tentunya dengan permasalahan-permasalahan yang bisa teratasi dengan adanya ROOSTER ini.Sehingga perbaikan mutu akan kualitas sistem pelayanan dukungan di setiap tahunnya dalam setiap perguruan tinggi akan mengalami peningkatan, sehingga dapat dilihat pada grafik diagram batang perkembangan perihal kualitas sistem pelayanan dukungan pada perguruan tinggi tersebut. 


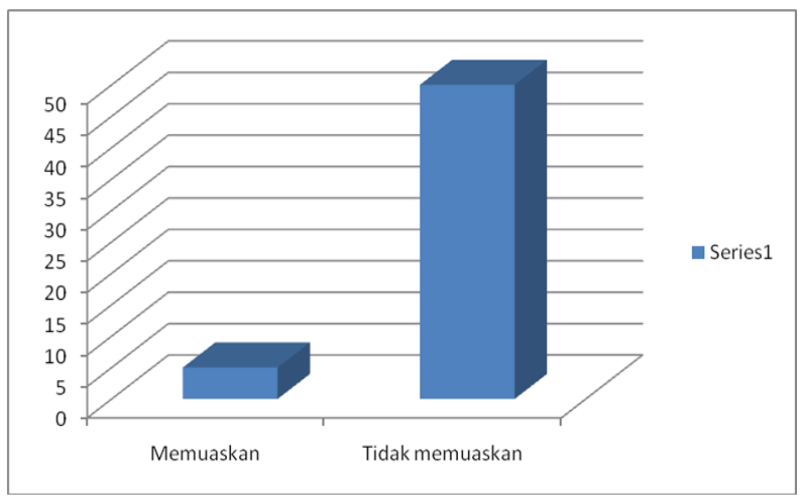

Gambar 4. Graph diagram batang kualitas sistem pelayanan dukungan

Tampak pada gambar diatas, merupakan tampilan grafik kualitas sistem pelayanan dukungan diagram batang pada Perguruan Tinggi Raharja perihal tanggapan dalam hal kepuasan dan keoptimalan tentang sistem pelayanan dukungan. Sebesar 9\% merasa puas akan pelayanan dukungan, sedangkan sebesar 91\% tidak merasa puas akan pelayanan dukungan.

Sedangkan jika diukur melalui statistik diagram pie, maka hasilnya adalah sebagai berikut:

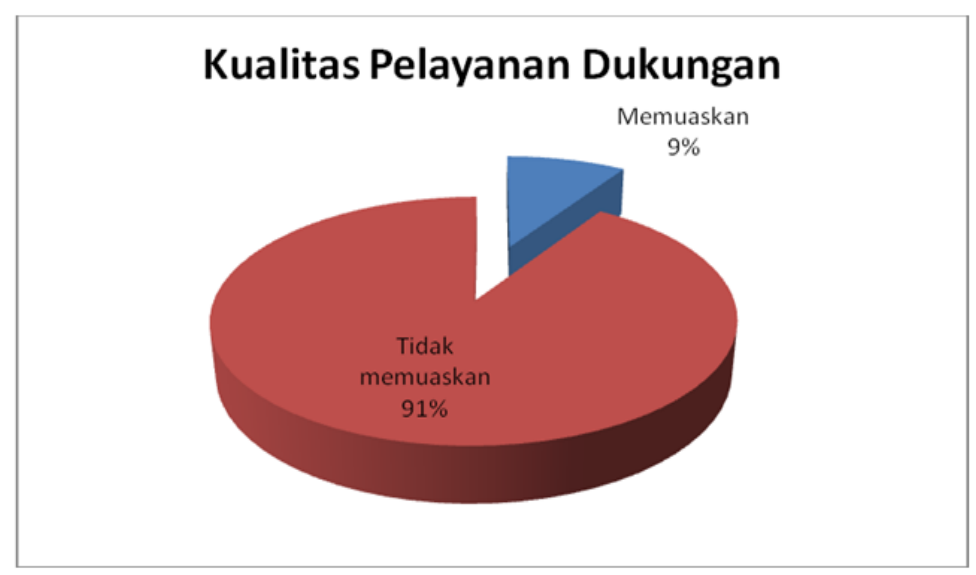

Gambar 5. Statistik diagram pie kualitas pelayanan dukungan berikut:

Dan jika diukur melalui statistik diagram garis, maka hasilnya adalah sebagai 


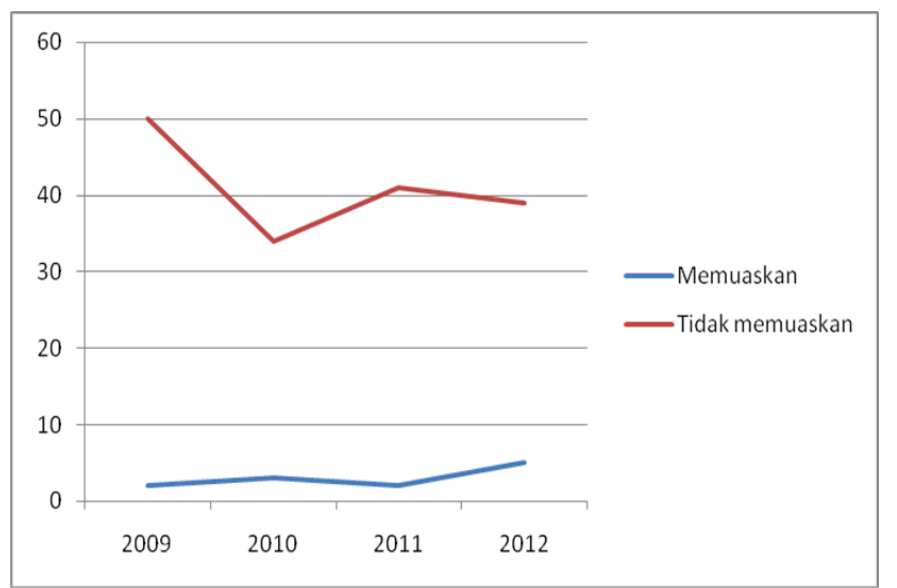

Gambar 6. Graph statistik kualitas pelayanan dukungan

Tampak pada gambar diatas, merupakan statistik grafik kualitas pelayanan dukungan yang dihitung setiap tahunnya.

\section{LITERATURE REVIEW}

Berkenaan dengan metode pembelajaran dan pengembangan pembelajaran telah banyak penelitian yang dilakukan sebelumnya. Diantaranya adalah mengidentifikasi kesenjangan (identify gaps), menghindari pembuatan ulang (reinventing the wheel), mengidentifikasi metode yang pernah dilakukan, meneruskan penelitian sebelumnya, serta mengetahui orang lain yang spesialisasi dan area penelitiannya sama dibidang ini. Beberapa Literature Review tersebut adalah sebagai berikut:

1. Penelitian ini dilakukan oleh John R. Olson dari University of St Thomas, Minneapolis, Minnesota, USA, pada tahun 2005 yang berjudul "Internet Ticketing In A Not-For-Profit, Service Organization: Building Customer Loyalty". Penelitian ini membahas tentang melihat cara-cara di mana internet telah mengubah cara di mana banyak organisasi sekarang melakukan bisnis. Internet telah membuat pemindahan informasi mudah tapi memenuhi pesanan online telah terbukti menjadi tantangan. Hasil penelitian menunjukkan bahwa pelanggan menyadari manfaat yang signifikan dari menggunakan internet untuk membeli tiket konser. Pelanggan juga 
menunjukkan bahwa mereka puas dengan pengalaman layanan internet mereka. Peran internet dalam organisasi akan berubah secara dramatis selama dekade berikutnya. Untuk organisasi yang mencoba untuk menggunakan internet sebagai media penjualan utama, mereka harus menyadari bahwa kesuksesan mereka bergantung pada pengembangan basis pelanggan yang berkelanjutan. Untuk organisasi yang didirikan, integrasi internet ke dalam bisnis yang ada akan menjadi salah satu kunci keberhasilan di masa depan[1].

2. Penelitian yang dilakukan oleh Ainin Sulaiman dari University of Malaya, Faculty of Business and Accountancy, Kuala Lumpur, Malaysia, pada tahun 2008 yang berjudul "E-ticketing as a New Way of Buying Tickets : Malaysian Perceptions”. Penelitian ini bertujuan menjelaskan tentang mengidentifikasi $e$-ticketing tren di kalangan masyarakat perkotaan khususnya di Kuala Lumpur. Mengkaji tren penggunaan dan pola e-ticketing. Selain itu, juga berfokus pada perspektif pelanggan menuju $e$-ticketing dalam hal, kehandalan kegunaannya, keamanan, kenyamanan dan efisiensi. Penelitian ini juga menguji dampak dari variabel-variabel demografi pada $e$-ticketing adopsi terhadap e-ticketing. Studi ini menemukan bahwa e-ticketing bukanlah fenomena baru karena hampir lima puluh persen dari responden telah membeli tiket secara online selama dua tahun terakhir dan pembelian tiket pesawat tampaknya mendominasi layanan tiket online. Itu juga menemukan bahwa kenyamanan dan kemudahan penggunaan adalah salah satu faktor yang memotivasi responden untuk membeli tiket online. Penelitian ini juga mengungkapkan bahwa pembeli tiket online adalah kaum muda, berpendidikan dan dengan pendapatan yang lebih tinggi[2].

3. Penelitian ini dilakukan oleh Farah Virnawati dan Tirta Paramitta dari Universitas Gunadarma, Indonesia, pada tahun 2007 yang berjudul “Optimalisasi Penentuan Keputusan Ticketing Online Bagi Costumer”. Penelitian ini membahas proses transaksi yang tadinya dilakukan secara konvensional bergeser menjadi proses transaksi yang dilakukan secara otomatis dan online. Dampaknya adalah semakin banyak kemudahankemudahan yang ditawarkan oleh berbagai produsen untuk menarik costumer. Penentuan keputusan yang diberikan oleh sistempun harus benar-benar mewakili keinginan costumer atau paling tidak mendekati dengan persyaratan yang diinginkan costumer. Oleh karena itu, semakin banyak kemudahankemudahan yang ditawarkan oleh berbagai produsen untuk menarik costumer, dengan memanfaatkan teknologi yang ada pada era ini[3]. 
4. Penelitian yang dilakukan oleh Ery Hartati dari STMIK MDP Palembang, Indonesia pada tahun 2008 yang berjudul " Sistem Pemesanan Dan Pembelian Tiket Bioskop Secara Online Dengan menggunakan Active Server Pages.Net Berbasis Web Dan Wireless Application Protocol”. Pada penelitian ini menjelaskan mengenai sistem pemesanan dan pembelian tiket bioskop. Interaksi pelanggan yang dulunya dilakukan secara fisik (person to person direct contact) mulai bergeser ke elektronik (communication through technology innovations) karena komunikasi secara elektronik relatif dapat dilakukan secara efisien, efektif, akurat, aman, nyaman, dan berkualitas. Sejak dulu hingga saat ini, penonton yang ingin membeli tiket bioskop harus mengantri di loket penjualan tiket untuk membeli tiket bioskop. Cara ini relatif tidak efektif karena penonton harus mengantri dalam antrian yang cukup panjang dan cukup lama. Solusi untuk membuat sistem baru yaitu dengan menggunakan sistem pemesanan tiket bioskop secara online dengan menggunakan Active Server Pages.net berbasis web dan Wireless Application Protocol (WAP). Pada sistem yang baru, penonton dapat melihat film yang akan ditayangkan di bioskop, mendapatkan informasi harga tiket pada bioskop yang berbeda lokasinya, mendapatkan informasi ketersediaan tiket dan lokasi tempat duduk, dan membeli tiket bioskop melalui web atau melalui handheld mobile device yang mendukung penggunaan WAP sehingga penonton tidak perlu lagi mengantri dan menghabiskan waktu untuk mengantri tiket bioskop[4].

5. Penelitian yang dilakukan oleh Untung Rahardja, Augury El rayeb, dan Heriyanto dari Perguruan Tinggi Raharja, Indonesia pada tahun 2010 yang berjudul “Pengolahan Jurnal Elektronik Dengan Online Jurnal System”. Pada penelitian ini menjelaskan mengenai sistem penampungan hasil-hasil riset. Namun sistem ini masih bersifat manual, belum menggunakan database terstruktur dan perlu melibatkan personil terkait untuk mengendalikan alur sistem serta penggunaan banyak kertas untuk berkas data sebagai pendukungnya. Sehingga sistem tersebut tidak berjalan secara maksimal. Maka perlua adanya sebuah online jurnal sistem yang dapat dijalankan secara langsung (self service), dapat pula berkomunikasi via-email (intranet), penggunaan sedikit kertas (paper less), serta sudah menggunakan database yang baik karena dapat memberikan dampak yang cukup signifikan terhadap kelangsungan 4 (empat) pilar IT e-learning hasil dari penelitian di lingkungan Perguruan Tinggi Raharja[5].

6. Penelitian yang dilakukan oleh Untung Rahardja, Sunar Abdul Wahid, dan Nia Haryani dari Perguruan Tinggi Raharja, Indonesia pada tahun 2009 yang berjudul “Analisis Kinerja Student Information Services Menggunakan 
Technology Accetance Model (TAM)”. Dalam penelitian ini penulis menjelaskan tentang analisa keoptimalan sebuah sistem pelayanan untuk ditindak lanjuti kekurangan sistem tersebut agar dapat menghasilkan sistem pelayanan yang lebih optimal dan dapat meningkatkan kepuasan user. Dalam hal ini Technology Acceptance Model lebih banyak digunakan. Metode ini membuat model tentang bagaimana pengguna mau menerima dan menggunakan teknologi. Penerapan model TAM kedalam analisa Student Information Services ditujukan untuk mengetahui sejauh mana kualitas pelayanan serta keoptimalan dari Student Informatin Services tersebut. Dengan melakukan analisa lebih lanjut maka kekurangan dari sistem tersebut dapat diketahui dan dilakukan penyempurnaan terhadap sistem[6].

7. Penelitian yang di lakukan oleh Henderi dan Abas Sunarya dari Perguruan Tinggi Raharja, Indonesia pada tahun 2008 yang berjudul "Peranan IT Governance Dalam Meningkatkan Kinerja Organisasi : Permasalahan, Rencana Pengembangan dan Strategi Penerapan”. Penelitian ini menjelaskan penerapan Information Technology (IT) dalam sistem kerja oleh berbagai jenis organisasi. Secara umum bertujuan untuk meningkatkan kinerja, mencapai tujuan dan sasaran, dan keunggulan kompetitif organisasi. Tetapi tidak semua organisasi yang telah memanfaatkan IT dapat mencapai tujuan tersebut dengan baik. Hal ini disebakan oleh berbagai permasalah diantaranya. Akar permasalahannya adalah para manajer dan pemimpin organisasi belum memahami dan belum menerapkan prinsip-prinsip IT governance dengan baik dalam penerapan IT pada sistem kerja organisasi [7].

8. Penelitian yang dilakukan oleh Henderi dan Padeli dari Perguruan Tinggi Raharja, Indonesia pada tahun 2009 yang berjudul "IT Governance - Support for Good Governance”. Penelitian ini menjelaskan bahwa melalui penerapan IT proses bisnis perusahaan dapat dilaksanakan lebih mudah, cepat, efisien dan efektif. IT juga menawarkan banyak peluang kepada perusahaan dan organisasi untuk meningkatkan dan mentransformasi produksi, pelayanan pasar, proses kerja, dan hubungan-hubungan bisnis. Agar dapat mengoptimalkan peranan IT dalam berbagai bidang maka setiap perusahaan dan organisasi hendaknya memiliki IT governance yang baik dan menerapkan prinsip-prinsip dan cara kerja good governance. Untuk dapat menghilangkan kekurangan atau kelemahan pada pelaksanaan kegiatan operasional dan pelayanan kepada costumer yang menjadi penghambat kinerja dan inovasi proses dan kegiatan bisnis perusahaan[8]. 
9. Penelitian yang dilakukan oleh Henderi, Ary Budi Warsito dan Ahmad Sidik dari Perguruan Tinggi Raharja, Indonesia pada tahun 2010 yang berjudul “Digital Library Modelling : Supporting For Knowledge Management”. Penelitian ini menjelaskan mengenai digital library modelling untuk mendukung penerapan model knowledge management, dan mempermudah perolehan informasi dan pengembangan ilmu pengetahuan dari perpustakaan. Digital library modelling dibuat menggunakan pendekatan unified modelling language (UML), dan digambarkan dalam bentuk : use case diagram, class diagram, state diagram, collaboration diagram, componet diagram, dan screen prototype. Dengan digital library berbagai informasi dan referensi ilmu pengetahuan akan lebih mudah dan cepat diakses, disaring, diolah, digunakan dan dikembangkan oleh publik tanpa dibatasi oleh ruang dan waktu[9].

10. Penelitian ini dilakukan oleh Anita B. Wandanaya dari Perguruan Tinggi Raharja pada tahun 2011 yang berjudul "Pengaruh Pemasaran Online Terhadap Keputusan Pembelian Produk.” Perusahaan dapat menerapkan suatu metode pemasaran dengan menggunakan media elektronik yang lebih murah yaitu internet, sehingga perusahaan dapat menekan biaya pemasaran serta dapat meningkatkan volume penjualan. Dengan menerapkan metode pemasaran ini maka dapat terjalin suatu hubungan antara pelanggan dengan produsen. Pemasaran melalui media internet memungkinkan suatu usaha untuk menjalankan praktek self-service. Suatu usaha dapat memberikan pelayanan kepada pelanggan tanpa membutuhkan tenaga SDM, mengurangi fasilitas dan layanan melalui telepon. Pemasaran online secara simultan, mempengaruhi pemrosesan informasi periklanan pelh para pengguna internet. Pemrosesan informasi periklanan oleh pengguna internet mempengaruhi keputusan pembelian[10].

Dari sepuluh Literature Review yang ada, telah banyak penelitian mengenai Internet Ticketing In A Not-For-Profit, E-ticketing as a New Way of Buying Tickets, Optimalisasi Penentuan Keputusan Ticketing Online Bagi Costumer, Sistem Pemesanan Dan Pembelian Tiket Bioskop Secara Online, Online Jurnal System, Kinerja Student Information Services Menggunakan Technology Accetance Model (TAM), Peranan IT Governance Dalam Meningkatkan Kinerja Organisasi, IT Governance - Support for Good Governance, Digital Library Modelling, dan Pemasaran Online. Namun dapat disimpulkan pula bahwa 
ISSN: 1978 - 8282

belum ada peneliti yang secara khusus membahas mengenai sistem pelayanan dukungan ROOSTER dengan menggunakan $e$-ticket pada perguruan tinggi.

\section{PEMECAHAN MASALAH}

Ada kelebihan yang dimiliki komputer dalam proses pengolahan data terlebih dalam pengelolaan data terhadap sistem pelayanan dukungan, ini merupakan penyebab mengapa komputer dijadikan sebagai alat pengolah data. Karena sistem komputerisasi bertujuan untuk mempercepat proses yang terjadi dalam suatu sistem khususnya dalam pelayanan dukungan tersebut. Ticketing online merupakan suatu sarana untuk meminta dukungan pelayanan dengan menggunakan e-ticket secara online dan realtime darimana saja dan kapan saja.

Konsep yang kemudian terkenal dengan sebutan online ini membawa pengaruh terjadinya proses transformasi pelayanan dukungan ke dalam bentuk digital, baik secara isi (contents) dan sistemnya. Saat ini konsep pelayanan dukungan online sudah banyak diterima oleh masyarakat dunia, terbukti dengan maraknya implementasi pelayanan dukungan online di lembaga pendidikan (sekolah, training dan universitas), industri maupun instansi-instansi lainnya.

Berdasarkan observasi, sistem pelayanan dukungan yang dilakukan pada Perguruan Tinggi Raharja sudah cukup baik, namun sejalan dengan kemajuan dan perkembangan teknologi serta pengembangan kebutuhan Pribadi Raharja pada umumnya atas pelayanan kepada seluruh civitas akademika, maka sistem ini memerlukan sistem yang benar-benar handal dan dapat berfungsi semaksimal mungkin untuk memberikan pelayanan dukungan serta dapat memenuhi permintaan layanan tersebut.

Untuk mencapai kepuasan user maka diperlukan sistem pelayanan dukungan yang optimal dan media yang dapat mempermudah user dalam mendapatkan pelayanan dukungan pada perguruan tinggi. Oleh karena itu, semakin banyak user disuguhkan dengan berbagai media dan sarana prasarana yang mendukung, maka semakin besar tingkat kepuasan user akan pelayanan dukungan yang diterima. Untuk mengatasi berbagai masalah diatas, maka diperlukan proses yang cepat dan efisien dalam mengakses seluruh data yang banyak dan tidak teratur pada sistem pelayanan dukungan, terlebih untuk suatu sistem informasi yang akurat. Sehingga memudahkan untuk proses pelayanan dukungan. Namun berdasarkan observasi, sistem pelayanan dukungan yang dilakukan pada perguruan tinggi saat ini sudah cukup baik, sehingga sejalan dengan kemajuan dan perkembangan teknologi serta pengembangan kebutuhan user pada umumnya. Atas kualitas pelayanan dukungan di perguruan tinggi secara umum maupun khusus kepada seluruh civitas akademika di perguruan 
tinggi, maka sistem ini memerlukan sistem yang benar-benar handal dan dapat berfungsi semaksimal mungkin untuk memberikan pelayanan dukungan serta memenuhi kebutuhan tersebut.

Oleh karena itu berdasarkan analisa dari segi kekurangan serta kebutuhan saat ini, kebutuhan terhadap sistem hendaknya sistem dapat mudah diakses dan user mendapatkan pelayanan secara optimal yang dibutuhkan oleh seluruh civitas akademika di perguruan tinggi, demi mengoptimalkan sistem pelayanan dukungan yang ada pada perguruan tinggi sehingga dapat memaksimalkan berbagai bentuk pelayanan kepada seluruh civitas akademika baik layanan yang dibutuhkan maupun keseluruhan. Selain itu dapat memberikan pelayanan yang optimal sehingga pelayanan yang didapatkan relevan sesuai dengan kebutuhan dan dapat memuaskan user.

Segala hal pada dasarnya untuk mengatasi berbagai masalah diatas, maka diperlukan proses yang cepat dan efisien dalam melayani seluruh permintaan pelayanan dukungan yang banyak dan teratur dalam media penyimpanan yang berupa sebuah website yang bisa diakses oleh jaringan internet dan di publish, terlebih untuk suatu sistem informasi yang akurat. Untuk menjelajahi dunia maya dengan mencari dan memperoleh informasi yang sangat relevan dan berkualitas serta memudahkan dalam proses pengambilan keputusan.

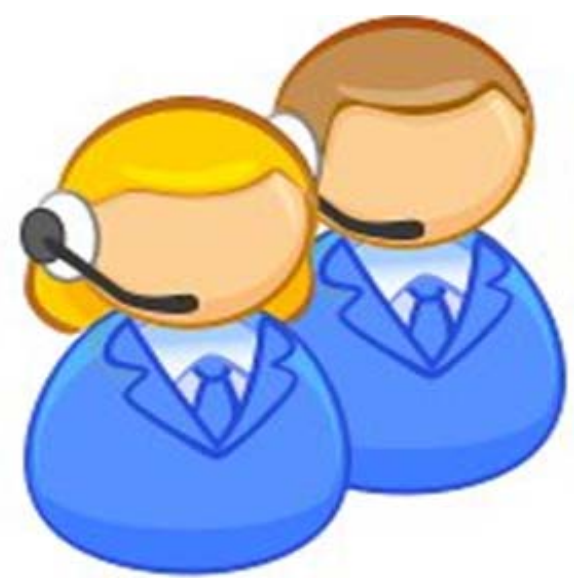

Gambar 7. Figure ilustrasi pelayanan dukungan

Pada gambaran figure ilustrasi pelayanan diatas, pelayanan dapat dilakukan pula dengan jalan alternatif yang memudahkan untuk melakukan proses tersebut, yaitu melalui alur flowchart. Dan dibawah ini merupakan gambaran flowchart alur program yang berjalan dari sistem pelayanan dukungan. 


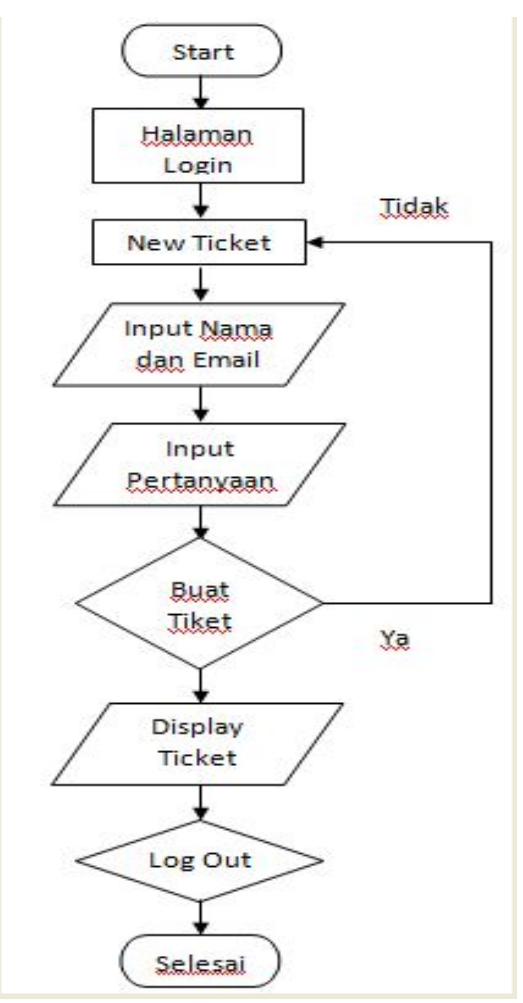

Gambar 8. Flowchart alur sistem pelayanan dukungan

Pemikiran ide yang akan dituangkan berdasarkan sumber-sumber informasi yang telah didapat. Sehingga rancangan aplikasi dimulai dengan mendapatkan open source osticket, dimulai dengan men-download open source osticket serta aplikasi pendukung dalam pengaplikasian osticket tersebut, yaitu dengan mengedit dan mengatur sesuai kebutuhan pada aplikasi dreamweaver.

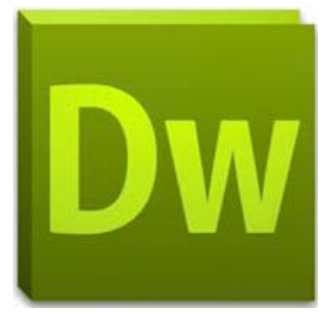

Gambar 9. Dreamweaver CS5 
Gambar diatas merupakan logo aplikasi dreamweaver yang digunakan untuk mendesain dan mengedit prototype sistem pelayanan dukungan. Dan pada tahap ini ide yang sebelumnya telah ada maka dituangkan dan di-upload kedalam aplikasi filezilla secara bertahap.

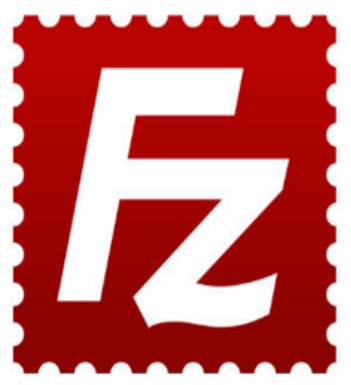

Gambar 10. Filezilla

Gambar diatas menunjukan bahwa tahapan selanjutnya dalam membuat sistem pelayanan dukungan ini setelah dirancang dan didesain dalam apilikasi dreamweaver lalu selajutnya dituangkan dan di upload dalam aplikasi filezilla. Dibuatnya dalam dreamweaver CS5 ini dimaksudkan untuk mempermudah dalam mendesign layout tampilan awal pada website tersebut.

Dalam pengaksesan sistem pelayanan dukungan berbasis website dalam ROOSTER ini, semua user baik itu yang telah lampau maupun yang akan datang, sebagai salah satu pendukung pelayanan dukungan, sehingga listing program yang akan ditampilkan yaitu listing program untuk program Login yang ada. Berikut listing programnya :

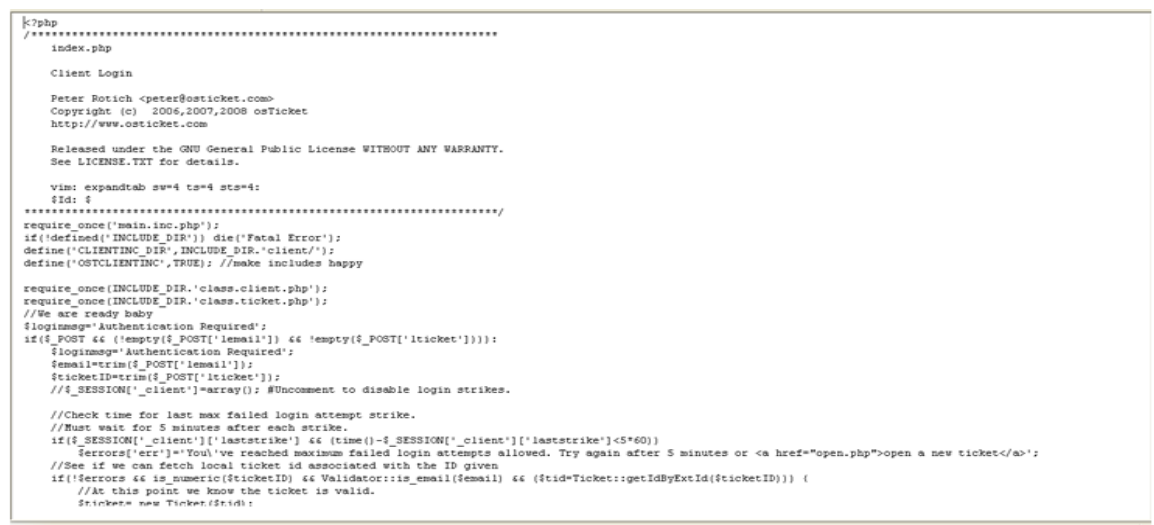

Gambar 11. Listing program login 


\begin{tabular}{|c|l|c|c|}
\hline No & \multicolumn{1}{|c|}{ Pertanyaan } & Ya & Tidak \\
\hline $\mathbf{1}$ & $\begin{array}{l}\text { Apakah aplikasi ROOSTER (Role Online System Ticketing } \\
\text { Raharja) mendukung proses sistem pelayanan dukungan? }\end{array}$ & $\mathrm{X}$ & $\mathrm{X}$ \\
\hline $\mathbf{2}$ & $\begin{array}{l}\text { Apakah dengan adanya aplikasi ROOSTER(Role Online System } \\
\text { Ticketing Raharja) dapat mempermudah dalam permintaan } \\
\text { pelayanan dukungan kampus? }\end{array}$ & $\mathrm{X}$ & $\mathrm{X}$ \\
\hline $\mathbf{3}$ & $\begin{array}{l}\text { Sudah sempurnakah sistem pelayanan dukungan sebelumnya ? } \\
\mathbf{4}\end{array}$ & $\begin{array}{l}\text { Apakah aplikasi ROOSTER(Role Online System Ticketing } \\
\text { Raharja) dapat diakses kapanpun dan? }\end{array}$ & $\begin{array}{l}\text { Apakah dengan adanya aplikasi ROOSTER(Role Online System } \\
\text { Ticketing Raharja) tingkat kepuasan user meningkat? }\end{array}$ \\
\hline $\mathbf{5}$ & $\mathrm{X}$ & \\
\hline
\end{tabular}

\section{Gambar 12. Tabel daftar pertanyaan}

Berdasarkan pada daftar tabel diatas, yaitu tabel pertanyaan sistem pelayanan dukungan diatas, bahwa perancangan dan pembuatan sistem pelayanan dukungan dapat mempermudah proses pelayanan dukungan yang sangat bermanfaat bagi seluruh civitas akademika. Oleh karena itu pembuatan sistem pelayanan dukungan layak untuk segera dibangun agar dapat meminimalisir permasalahan-permasalahan yang terjadi terkait sistem pelayanan dukungan.

Adapun 3(tiga) ciri khas ROOSTER yang merupakan konsep sistem pelayanan berbasis web, sehingga ciri khas yang pertama yaitu ROOSTER dapat mendeteksi kemungkinan-kemungkinan kesalahan yang terjadi pada sistem pelayanan dukungan. Yang kedua ROOSTER dapat mengantisipasi dan mencegah kemungkinan terjadinya kesalahan didalam sistem pelayanan dukungan dengan tepat dan akurat. Yang ketiga ROOSTER dapat digunakan sebagai media sistem pelayanan dukungan yang valid.

Sebelum adanya ROOSTER pelayanan dukungan sangat sulit di dapat. Maka dari rancangan tersebut aplikasi ini dapat menguraikan setiap permasalahan yang ada pada sistem sebelumnya. Sehingga disimpulkan 5 (lima) keunggulan dan pemecahan masalah yang ada pada sistem pelayanan dukungan. Pemecahan masalah yang pertama, yaitu dengan sistem berbasis web dan diimplementasikan secara online aplikasi ini akan mampu untuk menjawab beberapa permasalahan yang ada dikarenakan sistem ini akan dapat diakses dimanapun dan kapanpun selama dimungkinkannya terdapat koneksi internet yang baik. Pemecahan masalah kedua, aplikasi ini merupakan sistem web dinamis dimana sistem ini akan dapat dimanage secara berkala sehingga selalu up to date. Pemecahan masalah ketiga, aplikasi dibuat agar mampu memanage pelayanan dukungan yang dibutuhkan oleh user. Pemecahan masalah keempat aplikasi ini akan berjalan secara online sehingga mampu menangani 
setiap permasalahan yang ada dan memberikan nilai positif bagi setiap user yang mengaksesnya. Dan pemecahan masalah yang kelima yaitu aplikasi dapat digunakan sebagai bahan pertimbangan untuk pemecahan masalah bagi user.

\section{IMPLEMENTASI}

Prototype ROOSTER memiliki berbagai macam fitur yang dapat digunakan oleh seluruh civitas akademika yang terdiri dari :

a. Prototype logo ROOSTER

Pada prototype ini kita bisa melihat desain prototype logo ROOSTER.

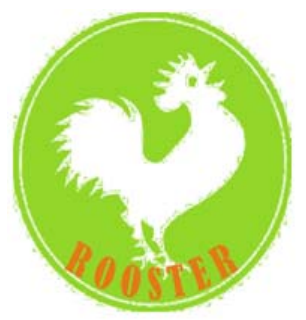

Gambar 13. Prototype logo ROOSTER

b. Prototype list tiket ROOSTER

Prototype ini menampilkan daftar list tiket ROOSTER

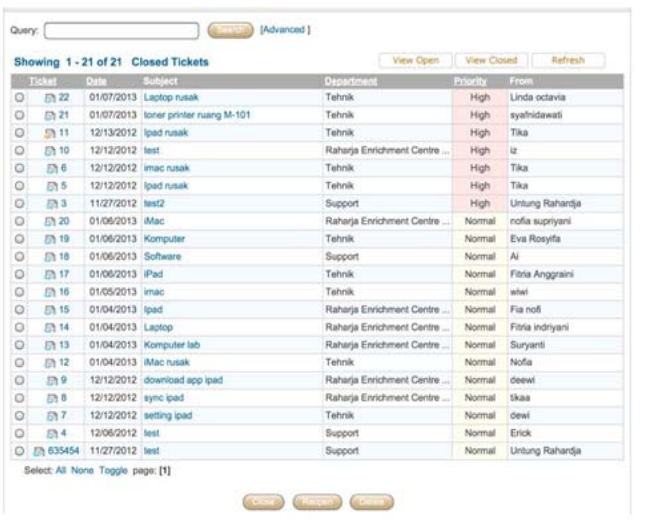

Gambar 14. Prototype list tiket ROOSTER

c. Prototype home ROOSTER

Dibawah ini merupakan prototype home ROOSTER 


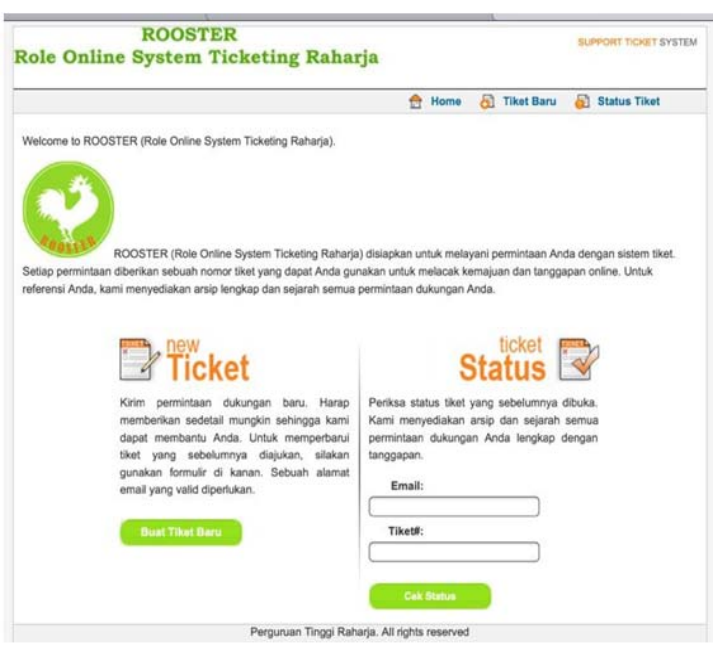

Gambar 15. Prototype home ROOSTER

d. Prototype formulir buat tiket ROOSTER

Dibawah ini merupakan prototype buat tiket ROOSTER.

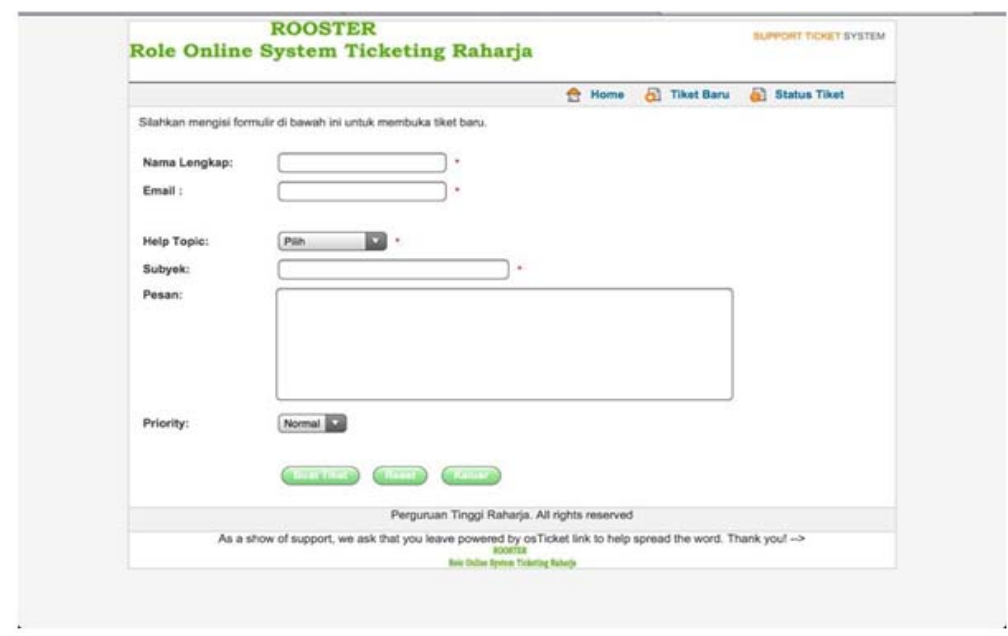

Gambar 16. Prototype formulir buat tiket ROOSTER

e. Prototype view tiket ROOSTER

Dibawah ini merupakan prototype view tiket ROOSTER. 


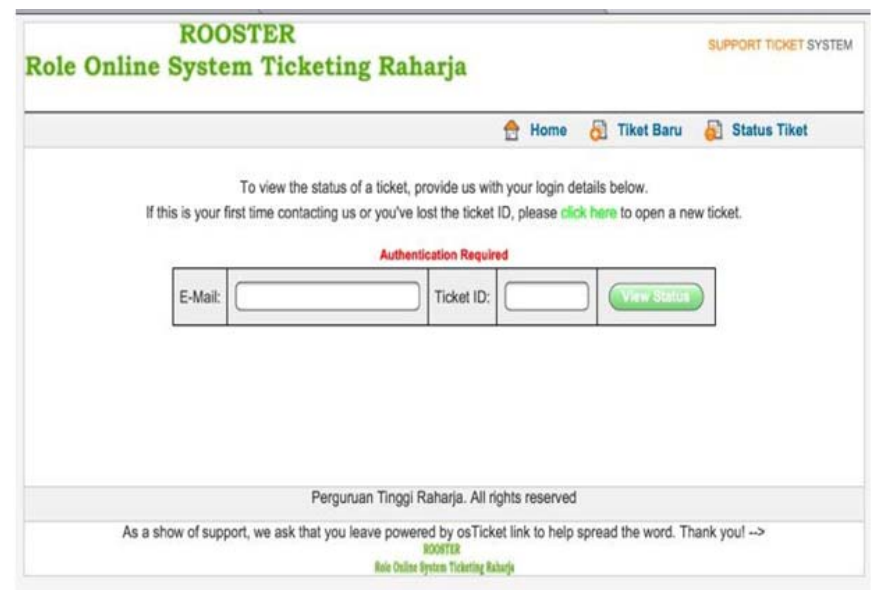

Gambar 17. Prototype view tiket ROOSTER

\section{KESIMPULAN}

Hasil penelitian ini diharapkan dapat bermanfaat oleh seluruh perguruan tinggi dan masyarakat luas sebagai media sistem pelayanan dukungan yang dapat diakses oleh seluruh civitas akademika dan masyarakat luas. Sehingga seluruh civitas akademika dan masyarakat mendapatkan pelayanan yang berinovasi, memuaskan dan dapat memaksimalkan berbagai bentuk pelayanan kepada seluruh civitas akademika dan masyarakat luas. Selain itu dapat memberikan pelayanan yang akurat dan up to date sehingga pelayanan yang didapatkan relevan dan sesuai dengan kebutuhan. Selain itu dapat digunakan sebagai bahan untuk mengambil suatu keputusan. Serta hasil penelitian ini bisa dijadikan referensi bagi penelitian sejenis dimasa yang akan datang. Khususnya untuk pengambilan keputusan dalam melakukan pengukuran kinerja organisasi pemerintah atau lembaga non profit termasuk perguruan tinggi didalamnya. Namun masih terdapat permasalahan harus dihadapi saat ini. Sehingga diidentifikasi terdapat 5 (lima) permasalahan yang ada dalam sistem pelayanan dukungan saat ini, yang secara detail menurut penjabarannya dicantumkan dalam aplikasi Mind Mapping. Terdapat pula beberapa literature review yang ada, diantaranya mengenai E-ticketing as a New Way of Buying Tickets, Internet Ticketing In A Not-For-Profit, Service Organization: Building Customer Loyalty, maupun Optimalisasi Penentuan Keputusan Ticketing Online Bagi Costumer. Namun penelitian ini yaitu menitik beratkan pada pembahasan mengenai pendekatan sistem pelayanan dukungan dan kelulusan upaya mengimplementasikan 
media iLearning yang ada pada saat ini. Didalamnya terdapat pula jalan alternatif yang memudahkan untuk melakukan proses tersebut, yaitu melalui view detail listing login sistem pelayanan dukungan. Sehingga diharapkan dapat memudahkan untuk proses pengambilan keputusan dan memberikan pelayanan dukungan yang optimal dan memuaskan.

Sehingga dapat disimpulkan dengan metode ROOSTER maka user akan lebih mudah untuk pengaksesan terhadap sistem pelayanan dukungan, sehingga sistem dapat berjalan dengan efektif dan efisien serta pelayanan yang diberikan akan semakin optimal dan tentunya memuaskan.

\section{DAFTAR PUSTAKA}

[1] Olson. John R. "Internet Ticketing In A Not-For-Profit, Service Organization: Building Customer Loyalty”. University of St Thomas, Minneapolis, Minnesota, USA, 2005.

[2] Sulaiman. Ainin. "E-ticketing as a New Way of Buying Tickets : Malaysian Perceptions”. University of Malaya, Faculty of Business and Accountancy, Kuala Lumpur, Malaysia.2008.

[3] Virnawati. Fara, Paramitta, Tirta. “Optimalisasi Penentuan Keputusan Ticketing Online Bagi Costumer”. Universitas Gunadarma, Indonesia. 2007.

[4] Hartati. Ery. "Sistem Pemesanan Dan Pembelian Tiket Bioskop Secara Online Dengan menggunakan Active Server Pages.Net Berbasis Web Dan Wireless Application Protocol”. STMIK MDP Palembang, Indonesia.2008.

[5] R.Untung., El Rayeb.Augury. Heriyanto. "Pengolahan Jurnal Elektronik Dengan Online Jurnal System”.Perguruan Tinggi Raharja, Indonesia.2010.

[6] R. Untung, Abdul Wahid. Sunar, Haryani. Nia. "Analisis Kinerja Student Information Services Menggunakan Technology Accetance Model (TAM)”. Perguruan Tinggi Raharja, Indonesia.2009.

[7] Henderi, Sunarya.Abas. "Peranan IT Governance Dalam Meningkatkan Kinerja Organisasi : Permasalahan, Rencana Pengembangan dan Strategi Penerapan”. Perguruan Tinggi Raharja, Indonesia.2008.

[8] Henderi, Padeli. “IT Governance - Support for Good Governance”. Perguruan Tinggi Raharja, Indonesia.2009.

[9] Henderi, Warsito. Ary Budi, Sidik. Ahmad. "Digital Library Modelling : Supporting For Knowledge Management”. Perguruan Tinggi Raharja, Indonesia.2010.

[10] Wandanaya, Anita B. "Pengaruh Pemasaran Online Terhadap Keputusan Pembelian Produk”.Perguruan Tinggi Raharja.2011. 